\title{
The Paris Agreement and climate change negotiations: Small Islands, big players
}

\author{
Timothée Ourbak $^{1}$ • Alexandre K. Magnan ${ }^{2,3}$
}

Received: 10 May 2017 / Accepted: 25 October 2017 /Published online: 15 November 2017

(C) Springer-Verlag GmbH Germany 2017, corrected publication [November/2017]

\begin{abstract}
Climate change poses an existential threat to Small Island Developing States (SIDS). They have played a leading role in raising awareness of climate change on the international stage and advocating for strong climate action, notably through the Alliance of Small Island States (AOSIS). Despite their heterogeneity, they succeeded in building a common diplomatic discourse and influencing strategy, and mobilized political leaders as well as talented negotiators and advisors.

Small Island States were a crucial group in the negotiating period up to, during the 21st Conference of the Parties to the United Nations Framework Convention on Climate Change (COP21), and for the entry into force of the Paris Agreement. SIDS succeeded to secure their special circumstances as vulnerable countries, demonstrated leadership in raising ambition to reduce greenhouse gas emissions to help secure an ambitious long-term temperature goal of limiting global warming to below $1.5^{\circ} \mathrm{C}$, and advanced the complex debate on loss and damage.

Small Island States face major challenges to advance their leadership on climate change moving forward: securing immediate actions for those particularly vulnerable countries and increasing their influence within and outside the climate change negotiations. For Small Island states, the $1.5^{\circ} \mathrm{C}$ goal
\end{abstract}

Timothée Ourbak

ourbakt@afd.fr

Alexandre K. Magnan

alexandre.magnan@iddri.org

1 Agence Française de Développement, 4, rue Roland Barthes, 75012 Paris, France

2 Institute for Sustainable Development and International Relations, Paris, France

3 UMR LIENSs 7266, University of La Rochelle-CNRS, La Rochelle, France should be considered "the visible part of the iceberg" for their diplomacy in a post-Paris context.

\section{Introduction}

Ever since its first assessment report, the Intergovernmental Panel on Climate Change (IPCC) has recognized Small Islands and atoll countries as being highly vulnerable to climate change, notably to sea level rise (IPCC 1990). Article 4.8 of the United Nations Framework Convention on Climate Change (UNFCCC) refers to "the specific needs and concerns of developing country Parties arising from the adverse effects of climate change ... especially on: (a) Small Island countries; (b) Countries with low-lying coastal areas; (c)..." (UNFCCC 1992). The Alliance of Small Island States (AOSIS) was created in 1990, ahead of the formal negotiations leading to the adoption of the UNFCCC, with the aim of raising the voice of Small Island Developing States (SIDS) within the United Nations system, particularly with regard to the environmental and climate change issues of that time.

The creation of such a coalition illustrates the paramount importance of climate change-induced threats for island communities, as well as the increase in their leaders' awareness of such issues. Sea-level rise, ocean warming and acidification, increased precipitation variability (droughts and rains), and extreme events such as cyclones, coral bleaching episodes, etc. pose serious threats to islands' long-term inhabitability for human societies, particularly in low-lying atoll reef islands (UNFCCC 2005; Nurse et al. 2014).

During the complex history of UNFCCC negotiations (e.g. Bodansky 2001), AOSIS members have been proactive in raising such concerns, using scientific arguments related to their special circumstances and claiming that climate change poses an existential threat to them. They have succeeded in efforts to 
"develop a specific negotiating agenda addressing areas which are of overriding concern to them and succeeded in having those concerns incorporated in a legally binding Convention of historic importance" (Ashe et al. 1999, p. 209). Notably, they played an important role in establishing the climate change convention and thereafter, they continued to play a very dynamic and successful role in the climate negotiation process itself, for example, in the shaping of the Copenhagen Accord negotiation process in 2009 (Benjamin 2011; de Águeda Corneloup and Mol 2014). Therefore, despite their modest demographical, economic and political weight in the multilateral system in general and in the context of an asymmetric negotiation power (Zartman and Rubin 2002), they have been instrumental in the climate change talks (AOSIS 2017) in bringing an ambitious and progressive voice to the table.

In the lead up to COP21, parties released their Intended Nationally Determined Contributions (INDC), which could be seen as national climate plans, and more importantly as the foundations of the new climate regime (UNFCCC 2016a). Despite the heterogeneity of AOSIS member States (both Least Developed Countries (LDC) and richer countries, not all are islands stricto sensu) and their low share of in global greenhouse gas emissions (Hoad 2015), most of them included ambitious mitigation targets in their INDCs. This reflects AOSIS' commitment to transforming their economies into low carbon economies and to raising collective ambition. Highlighting their limited leeway for action in terms of mitigation also represents for Small Islands a way to emphasize their needs in terms of adaptation, and thus in terms of financial provisions for adaptive response measures to the adverse impacts of climate change, such as sea level rise (Ashe et al. 1999).

From a political perspective, many leaders from AOSIS members, heads of states and heads of governments or ministers, have made climate change a focus of their international diplomacy. As stated by Betzold (2010, p. 142), they have had "relative to their size, a disproportionate influence on the climate change regime" by borrowing power. For instance, they have been very successful in raising awareness of their case in the media and within the United Nations system, alerting the world to their specific circumstances and in particular, their potential disappearance due to accelerating sea level rise. A well-known example is the underwater cabinet meeting held by the government of Maldives a few weeks prior to the Copenhagen conference to highlight the threat of climate change for low-lying nations (BBC 2009). De Águeda Corneloup and Mol $(2014$, p. 281) have also detailed how SIDS define common positions, often speak with one voice, defend their group's position by using "entrepreneurial, intellectual, and environmental leadership strategies" and manage to secure most of their position in the final negotiating texts, building on coalitions with parties and non-state stakeholders.

With this background, this paper questions the role of AOSIS in climate change negotiations during the past years and then comments on the challenges ahead. This commentary grows out of the lead author's experience in conducting dialog with low-lying countries within the French COP 21 Presidency and is structured in two main parts.

First, it focuses on how the group is structured and the role of AOSIS in climate change negotiations in recent years and how it helps those vulnerable countries. It analyses AOSIS successes by demonstrating the coalition's role in securing SIDS' special circumstances as vulnerable countries and highlights its leadership in encouraging greenhouse gas emissions reductions by setting an ambitious long-term temperature goal (i.e., the below $1.5^{\circ} \mathrm{C}$ warming target), as well as in pushing for the establishment of the principle of loss and damage. It also presents the Paris Agreement ratification process and the role of islanders therein.

Second, it discusses major challenges for AOSIS in the years to come in advancing its global leadership further: immediate actions for those whom climate change poses an existential threat and the ways to increase Small Islands' influence in and outside the climate change negotiations. In doing so, the paper advocates for considering the $+1.5^{\circ} \mathrm{C}$ target as "the visible part of the iceberg" for SIDS diplomacy, in a post Paris context.

\section{AOSIS: a crucial group in the negotiating period up to, during the 21st Conference of the Parties, and for the entry into force of the Paris Agreement}

\section{Structure of the group and role of Small Island Developing States leaders}

AOSIS is heterogeneous, with a range of geographical, cultural, social, and economic differences (de Águeda Corneloup and Mol 2014). For instance, some members of AOSIS are also members of the LDC (Comoros, GuineaBissau, Haiti, Kiribati, Sao Tomé and Principe, Solomon Islands, Timor-Leste, Tuvalu, and Vanuatu), while others are more wealthy countries (e.g., Singapore, Trinidad and Tobago). AOSIS is composed of 44 United Nations members (39 members-mainly SIDS-plus 5 observers ${ }^{1}$ ) representing $28 \%$ of developing states, $20 \%$ of the United Nations membership, but only about $5 \%$ of the world population. Although not all of its members are islands stricto sensu (e.g., Guyana) or "small” (e.g., Papua New Guinea), they are all at the frontline of climate change impacts, with induced existential threats. From a political point of view, SIDS also represent various political contexts and have regional constituencies.

Despite this, SIDS have succeeded in building common diplomatic discourse and influencing strategy. This resulted, in part, from the emergence of a series of vocal political leaders, well known in the realm of climate change. These include,

\footnotetext{
${ }^{1}$ See http://aosis.org/members/ for the list of the members.
} 
among others, ${ }^{2}$ for Pacific SIDS (PSIDS), for example, Mr. Enele Sopoaga, Prime Minister of Tuvalu and primary spokesman for AOSIS during the fifteenth conference of the parties (COP15 in Copenhagen in 2009), Mr. Tony de Brum, Minister of Foreign Affairs of the Republic of Marshall Islands, or Mr. Anote Tong, President of the Republic of Kiribati. These leaders have generated momentum by setting up meetings in advance of COP21, such as that which produced the Majuro declaration in 2013 (PIF 2013) helping to raise the profile of climate change and expectations surrounding COP21. In 2015, in the Caribbean, Mr. James Fletcher, Minister of Environment, Energy, Science and Technology, of Saint Lucia and Mr. Freundel Stuart, Prime Minister of Barbados, also played a crucial role, building a block around the CARICOM community. Finally, the lead came from the Indian Ocean, as the Maldives held the AOSIS Presidency. Ministers Thoriq Ibrahim (Maldives), Vivian Balakrishnan (Singapore), and, to a lesser extent, Jean Paul Adam (Seychelles), played important roles, for example, by raising their voices in various formal and informal negotiation meetings in the run up and during COP21.

AOSIS machinery was also fueled by talented negotiators and advisors, thus facilitating the process. This helped AOSIS to stand as a block, even if differences with and within regions became clear during the COP21 negotiations themselves. For instance, PSIDS had their own meetings, separate from the other SIDS. Some even negotiated at several levels, such as the Tuvalu delegation with Ambassador Ian Fry, who was also representing the LDC group in the negotiation, ensuring that their positions were taken into account and voiced by different groups.

\section{What they pushed for and got at the 21st Conference of the Parties}

Although under capacity constraints, for instance, the small size of AOSIS delegations during COP21, the Paris Agreement is for AOSIS "a good outcome, albeit not a great one" (Fry 2016, p. 105). AOSIS had three main positions, or "red lines" that its members stated both during formal and informal meetings in preparation for COP21 and which were repeated officially during the last days of negotiation at COP21 (AOSIS 2015a).

First, AOSIS fought for the recognition of Small Island' special circumstances and needs as particularly vulnerable countries. The fifth paragraph of the preamble of the Paris Agreement refers to the climate change convention, a first diplomatic victory for SIDS. In the final text of the Paris Agreement, SIDS (together with LDCs) appear five times regarding mitigation, finance, capacity building, and transparency issues (UNFCCC 2015a). Up until the last hours of negotiations, SIDS resisted the call from other groups or regions to also be cited explicitly as "vulnerable countries", primarily to

\footnotetext{
${ }^{2}$ The list is arbitrary but reflects, on the authors points of view, a balance list of the most influential and vocal leaders at that time.
}

secure their preferential access to climate finance (Klein and Möhner 2011). AOSIS succeeded in keeping their special circumstances regarding flexibility in the reporting system and the new transparency framework, and avoiding any additional burden in terms of reporting activities. However, AOSIS was asking for special access to finance, especially finance for adaptation. The language related to finance in the Paris Agreement "might be considered as a victory for SIDS" (Hoad 2016, p.318), although they did not succeed in obtaining one of their key asks related to "....provisions to enhance SIDS access, especially to public, grant-based support for adaptation, given our unique challenges and the existential threat..." (AOSIS 2015a). In the end, this represents a success for developing countries as a whole, not only and specifically for SIDS.

Second, AOSIS fought for a legally binding ambitious agreement. Since 2008, and based on the above-mentioned historical special circumstances red line, AOSIS has been advocating for the recognition of an ambitious temperature target to be the goal for global emission reduction, i.e., below $1.5^{\circ} \mathrm{C}$ warming by the end of the century compared to pre-industrial levels. The accomplishment for AOSIS, in the run-up to COP21, consisted in initiating a negotiating agenda item called the "structured expert dialogue" that led to a final report mentioning the $+1.5^{\circ} \mathrm{C}$ target (Benjamin and Thomas 2016). AOSIS also played a critical role in gaining support for this $+1.5^{\circ} \mathrm{C}$ target from other vulnerable countries such as African countries, members of the LDC group and also Asian countries, and by advocating for this target to be considered in other fora a such as the IPCC (Ourbak, personal observation). By the time negotiators reached Paris, more than hundred countries were advocating for this level of ambition (Mathiesen and Harvey 2015), despite strong reluctance from major emitters. SIDS succeeded, along with other actors and owing to a sophisticated communication strategy, for example, in close collaboration with the Climate Vulnerable Forum (Climate Vulnerable Forum 2015) or the High Ambition Coalition, in getting this reference included within the Paris Agreement's Article 2 on the mitigation long-term goal. Moreover, paragraph 21 of decision 1/CP21 (UNFCCC 2015b): "invites the Intergovernmental Panel on Climate Change to provide a special report in 2018 on the impacts of global warming of $1.5^{\circ} \mathrm{C}$ above pre-industrial levels and related global greenhouse gas emission pathways". SIDS have secured a scientific assessment regarding the $+1.5{ }^{\circ} \mathrm{C}$ goal to be produced based on best available science and to inform the negotiations ahead of the "facilitative dialogue", the first milestone for the Paris Agreement to be held in 2018 at COP24 (paragraph 20 of decision 1/CP21 (UNFCCC 2015b).

Third, AOSIS fought for the recognition of loss and damage to be embedded in the Paris Agreement. The concept is not new in the negotiations, as AOSIS was already advocating for it to be embedded in the climate convention in the 1990s. In a nutshell, it is a legally loaded concept reflecting compensation and liability issues (Adelman 2016), which is broadly defined under the 
UNFCCC as "the actual and/or potential manifestation of impacts associated with climate change in developing countries that negatively affect human and natural systems" (Rajamani 2015, p.17). From an AOSIS perspective, climate change poses an existential threat associated with the loss and damage they are likely to suffer. After intense political and technical negotiations, AOSIS succeeded in attaining a stand-alone article on loss and damage (article 8), separated from adaptation. Although the decision attached to the Paris Agreement clearly mentions that "the Article 8 of the Agreement does not involve or provide a basis for any liability or compensation" (paragraph 51 of decision 1/CP. 21 ), a red line for many countries, this has represented a clear success for AOSIS, albeit reduced by the above mentioned paragraphs as well as the absence of a clear funding stream (Burkett 2016). The Paris outcome also strengthened the Warsaw International Mechanism on loss and damage and proposed the establishment of a "clearing house for risk transfer that serves as a repository for information on insurance and risk transfer, in order to facilitate the efforts of Parties to develop and implement comprehensive risk management strategies" (paragraph 48 of decision 1/CP21) and a task force which will "develop recommendations for integrated approaches to avert, minimize and address displacement related to the adverse impacts of climate change" (paragraph 49 of decision 1/CP21). Those two paragraphs are also very important for AOSIS (Burkett 2016).

AOSIS deserves credit for another important aspect of the Paris Agreement. Indeed, it has been asking for "champions" to help raise climate change ambition and actions in the so-called Workstream 2-pre-2020 ambition of the Ad Hoc Working Group on the Durban Platform for Enhanced Action (ADP) of the UNFCCC. The ADP is a subsidiary body established at COP17 (Durban, South Africa) in order "to develop a protocol, another legal instrument or an agreed outcome with legal force under the Convention applicable to all Parties, which is to be completed no later than 2015 in order for it to be adopted at the twenty-first session of the Conference of the Parties (COP) and for it to come into effect and be implemented from 2020". ADP thus laid the foundations for the Paris Agreement. AOSIS has been successful in that a "high level event", together with the appointment of two "high level champions to dramatically scale up pre-2020 action" - another ask for AOSIS leaders (AOSIS 2015a) - are now embedded in the Paris Agreement (paragraphs 120 and 121 of decision 1/CP.21). Since COP22 in November 2016, and until COP24 in 2018, one of the two high level champions is M. Inia Seruiratu, the Minister for Agriculture, Rural and Maritime Development and National Disaster Management, from Fiji.

The Paris Agreement struck a delicate balance of positions among all groups and countries and the final document agreed upon contained the main AOSIS positions: no "watering down" of their status, the inclusion of the below $+1.5^{\circ} \mathrm{C}$ target as a longterm goal (together with the below $+2{ }^{\circ} \mathrm{C}$ target), and the permanence of the concept of loss and damage, with a separate article, as well as inclusion of the concept of climate justice (Hoad 2016). They also played an important role in securing and encouraging immediate actions to fight against climate change.

\section{Universal ratification}

In the aftermath of COP21 and adoption of the Paris Agreement, one of the biggest challenges in 2016 was the ratification process. According to Decision 1/CP.21 of the Paris Agreement (UNFCCC 2015b), the "Agreement shall enter into force on the thirtieth day after the date on which at least 55 Parties to the Convention accounting in total for at least an estimated 55 per cent of the total global greenhouse gas emissions have deposited their instruments of ratification, acceptance, approval or accession" (Article 1.21 of the Paris Agreement). AOSIS could not do a lot to achieve the 55\% of the emissions target, being responsible for only a few percent of global emissions. However, Small Island States once again took the lead at the global level. Fiji was the first country to ratify, followed a few days later by the Republic of Marshall Islands, Palau, the Maldives, and others. This is not new stance for Small Island States, as Mauritius was the first to ratify the climate convention, quickly followed by the Seychelles and the Marshall Islands. Also, Fiji and Antigua and Barbuda were the firsts to ratify the Kyoto Protocol. AOSIS members have used their moral power (Betzold et al. 2012; de Águeda Corneloup and Mol 2014) which helped increase the number of countries that have ratified by putting pressure on the major emitters. The Paris Agreement entered into force on 4 November 2016 and by September 27 of 2017, 166 parties had ratified it, while only two countries (Surinam, Trinidad and Tobago) from AOSIS had not (UNFCCC 2017a).

\section{AOSIS challenges for the years to come}

These successes, although they result from AOSIS members' longstanding diplomatic efforts, remain fragile by nature. To strengthen them, AOSIS now needs to address at least two major interrelated issues.

\section{Immediate actions}

Island communities are already suffering from climate change impacts in various ways (Nurse et al. 2014; UNFCCC 2005) and the response of political leaders to their communities has been to raise an ambitious voice in climate negotiations, providing solutions on the ground and advocating for immediate actions.

The appointment of high-level champions and the gathering of leaders at the high-level event mentioned in paragraph 2.2 above is a response to that call. AOSIS has led the negotiation effort that ultimately created the high-level champions, pushing for the creation and strengthening of multi-stakeholders' initiatives. AOSIS has been instrumental in establishing and raising 
the profile of these kinds of immediate actions, which are multisectorial and stem from various actors (cities, regions, business communities, etc.). A platform is now operational and the NonState Actor Zone for Climate Action (NAZCA) platform presents "more than 70 cooperative initiatives involving almost 10 000 players from 180 countries" (UNFCCC 2016b). All stakeholders fighting against climate change can be part of coalitions and initiatives on buildings, transport, renewable energy, water, oceans, early warning systems, agriculture, etc. Many of these initiatives could be of paramount importance for SIDS, such as SIDS lighthouse, SIDS docks, the international solar alliance with a specific SIDS window, the Climate Risk and Early Warning Systems (CREWS), etc. ${ }^{3}$

An important gap for SIDS which may be discussed in future COPs could be the enhancement of more concrete actions to address coastal risks at the crossroads of extreme events (e.g. cyclones) and gradual changes (especially sea level rise, ocean warming and ocean acidification), for instance, moving from political to engineering and then to communitydriven actions, and eventually allowing discussions on the respective benefits and limitations of such options. In the mitigation area, this is also an opportunity for SIDS to raise issues such as new scientific insights on technological implications of zero emissions (Schleussner et al. 2016) or to take up the idea of carbon legislation with a roadmap for rapid deep decarbonization (Rockström et al. 2017). Finally, as institutional capacity is of critical importance for SIDS as mentioned in Article 11 of the Paris Agreement, and is often a key constraint, SIDS could benefit from capacity building support, as well as finance and technology transfer.

\section{Alliance of Small Island States leadership in the climate change negotiation arena}

AOSIS and its members have a proven record of dynamism and effectiveness in the climate negotiation arena. However, their positions are regularly challenged and there are at least three areas of progress for AOSIS to pursue.

During the discussions surrounding the recognition of the special status of the group of countries, AOSIS built a coalition with the LDC group, which also has specific provisions in the climate convention and in the Paris Agreement. The discussions inside the Group of 77 (G77), a group of negotiators encompassing 134 developing countries, were difficult to secure this "status" as, with increasing impacts over time, more countries are claiming to be particularly vulnerable to climate change and require special circumstances. While AOSIS will continue to make sure its members' special circumstances and needs will be highlighted in upcoming UNFCCC decisions, it should continue to exert a profound and continuing impact on

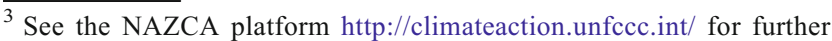
information.
}

global climate policy (Davis 1996) and seek to embrace the dynamics of other coalitions such as the Climate Vulnerable Forum and the High Ambition Coalition. SIDS may want to use their moral leverage (Betzold, Castro and Weiler, 2012) to gain visibility both within and outside the UN negotiations.

On the below $+1.5^{\circ} \mathrm{C}$ goal, AOSIS may use the results of the dedicated IPCC special report to ask for greater ambition, especially given the fact that implementation of existing NDCs with the current level of ambition will not lead to keeping global temperature rise to below $+2{ }^{\circ} \mathrm{C}$, let alone $+1.5^{\circ} \mathrm{C}$ (UNFCCC 2016a). Based on the outline report which has been agreed to at the IPCC 44th plenary (IPCC 2016), the report that will be delivered at the end of 2018 may present more scientific arguments to help AOSIS ask for higher ambition. On the other hand, the special report may note that a $+1.5^{\circ} \mathrm{C}$ world will present fewer risks than $\mathrm{a}+2{ }^{\circ} \mathrm{C}$ world, or that those risks associated with the difference of impacts between a $1.5^{\circ} \mathrm{C}$ and a $2{ }^{\circ} \mathrm{C}$ warming may be more important in non-island regions, such as deserts or continental territories. Such scientific results could undermine SIDS' specificity and leadership position. How the IPCC special report on $+1.5^{\circ} \mathrm{C}$ will impact AOSIS diplomacy is still to be determined, but it will definitely play a role in AOSIS members' ability to continue to highlight their strong exposure to the negative effects of climate change, and to forge wide coalitions to raise collective ambition towards a low emission world. A challenge for AOSIS members, based on their pioneering position, now consists in pressuring the international community to follow through with ambitious implementation of the Paris Agreement. To this end, the next milestone will be the UNFCCC 2018 facilitative dialogue.

On loss and damage, AOSIS is focusing on the opportunity to raise the topic's profile, and to develop concrete responses, such as financial instruments or comprehensive risk management approaches. However, it is also important to have a sound understanding of the potential risks. For instance, with work advancing on loss and damage, and even at $1.5^{\circ} \mathrm{C}$ of warming, it is possible that the scientific evaluation of the origin of the impacts and associated losses demonstrates the predominant role of anthropogenic drivers of risk rather than climate-related drivers (Duvat et al. 2017). This may result in blaming the responsible parties for maladaptation (Magnan et al. 2016). Examples are numerous in the area of coastal management practices, e.g., coastal urbanization, overuse of hard coastal defenses, land-based pollution degrading coral reefs, etc., even though coastal areas are sometimes the only viable areas of development for certain SIDS. Such conclusions might have unexpected negative impacts on adaptation finance in the future.

One final opportunity for the group is related to the leadership foreseen not only for the next COP presidency, but also for new coalitions which play a significant role in climate change talks. The High Ambition Coalition has been pursuing a more critical role since its formation before the Paris Agreement adoption at COP21. The Climate Vulnerable Forum is gaining 
weight in several fora and the future presidency should be the Republic of Marshall Islands. How those Presidencies will put the islands' interests at the center of the two coalitions, but at the same time, broadening climate action and the implementation of the Paris Agreement is still to be seen.

\section{Conclusions}

The IPCC special report on a $1.5{ }^{\circ} \mathrm{C}$ warmer world will be a milestone regarding the implementation of the Paris Agreement and for highlighting the circumstances of SIDS. New insights on the impacts they will have to deal with are likely to be included, for instance. However, this paper argues that the fight for recognition of the $+1.5^{\circ} \mathrm{C}$ goal should only be seen as "the visible part of the SIDS diplomacy iceberg".

It will thus be of crucial importance for AOSIS to continue to frame climate change as "a matter of life or death" (words pronounced by Head of State Hilda Heine of the Republic of Marshall Islands in September $2016^{4}$ but part of AOSIS discourse for a long time) and raise the profile of climate change issues not only in the negotiation rooms but also before the vast public audience. AOSIS members have proven that with their political and diplomatic skills, they can play a central role in climate change negotiations. They have proven themselves able to "influence through strategic framing, and ...enhance their influence through alliances and advocacy networks" (Jaschik 2014, p. 272). The Paris Agreement has now entered into force and AOSIS should continue to play a central role in helping to keep the momentum not only to implement climate actions (for example, if an AOSIS country is the first one to fully implement its NDC), but also to negotiate the rulebook of the Paris Agreement.

During the closing ceremony of COP21, 13 out of the 58 countries that took the floor were AOSIS members. As the AOSIS Presidency stated in its closing statement of COP21:

Indeed, this is an historic agreement, though we must remember that history will judge us not by what we did today, but by what we do from this day forward. That is how the Paris agreement will be measured: by future generations (AOSIS 2015b).

Through their experience in international climate negotiations, in particular the Paris Agreement that has further solidified the ability of SIDS to continue their leadership roles in other international fora, Small Island States at large fully realize their potential for leadership on other international issues as well, particularly related to the environment. The Republic of Marshall Islands was the first country to ratify the Kigali Amendment to

\footnotetext{
$\overline{{ }^{4} \text { See the entire }}$ article http://www.samoaplanet.com/climate-change-is-amatter-of-life-and-death-for-the-marshall-islands/
}

the Montreal Protocol on Substances that Deplete the Ozone Layer on the 28 February 2017 (UNFCCC 2017b). Fiji had the presidency of the Oceans Conference related to the Sustainable Development Goal number 14 in June 2017. Oceans and climate change are closely linked and Fiji has a unique opportunity to bring attention to the political momentum around this very important issue for "ocean states" (Wong 2011). Fiji will also be the UNFCCC COP23 President, and aims at making it what they call "an island COP with signature events" and also to lead the way to a fructuous facilitative dialogue.

While being vocal at the level of international politics can help Small Island communities move towards a more sustainable future, it is also important to recognize that gaps can exist between political discourses at the international level and practical challenges on the ground. These include rapid, international, and national "migration" of island communities or the fortification of islands to prevent coastal risks. It will thus be key in the future for AOSIS members to also pay attention to ensure that discourses and practices are mutually consistent, reducing the risk of destroying their credibility and undermining their diplomatic efforts of recent decades. An opportunity will be, for example, the development and implementation of their long-term low carbon strategies, one of the keys of the Paris Agreement (Ourbak and Tubiana 2017).

Acknowledgments The authors would like to thank the three reviewers and the editor-in-chief, the special issue coordinator, and the guest editor for their comments which help improve the strength and quality of the manuscript. The authors would also like to thank James Reese and Ken Xie for their help.

\section{References}

Adelman S (2016) Climate justice, loss and damage and compensation for small island developing states. J Hum Rights Environ 7(1):3253. https://doi.org/10.4337/jhre.2016.01.02

AOSIS (2015a) AOSIS ministers lay out priorities ahead of week two. http://aosis.org/press-release-aosis-ministers-lay-out-prioritiesahead-of-week-two/. Accessed 28 Sept 2017

AOSIS (2015b) AOSIS closing statement Paris Agreement. http://aosis. org/closing-statement-paris-agreement/. Accessed 28 Sept 2017

AOSIS (2017) Alliance of Small Island States: 25 years of leadership at the United Nations. http://aosis.org/wp-content/uploads/2015/12/AOSISBOOKLET-FINAL-11-19-151.pdf?bcsi_scan_cabb249f18b09402= 0\&bcsi_scan_filename=AOSIS-BOOKLET-FINAL-11-19-151.pdf

Ashe JW, Van Lierop R, Cherian A (1999) The role of the Alliance of Small Island States (AOSIS) in the negotiation of the United Nations Framework Convention on Climate Change (UNFCCC). Nat Res Forum 23:209-220. https://doi.org/10.1111/j.1477-8947.1999. tb00910.x

BBC (2009) Maldives cabinet makes a splash. http://news.bbc.co.uk/2/hi/ 8311838.st. Accessed 28 Sept 2017

Benjamin L (2011) The role of the Alliance of Small Island States (AOSIS) in UNFCCC Negotiations International Environmental Law-making and Diplomacy Review 2010 Ed Couzens and Tuula Honkonen (editors).117-133. doi: https://doi.org/10.1111/j.14778947.1999.tb00910.x 
Benjamin, Thomas (2016) 1.5 to stay alive? AOSIS and the long-term temperature goal in the Paris Agreement. IUCN eJ 7:122-129

Betzold C (2010) 'Borrowing' power to influence international negotiations: AOSIS in the climate change regime, 1990-1997. Politics 30(3):131-148. https://doi.org/10.1111/j.1467-9256.2010.01377.x

Betzold C, Castro P, Weiler F (2012) AOSIS in the UNFCCC negotiations: from unity to fragmentation? Clim Pol 12(5):591-613. https:// doi.org/10.1080/14693062.2012.692205

Bodansky D (2001) The history of the global climate change regime. In: Luterbacher U, Sprinz D (eds) International relations and global climate change, vol 161. The MIT Press. Cambridge, Massachusetts \& London, pp 23-40

Burkett M (2016) Reading between the red lines: loss and damage and the Paris outcome. Climate Law 6:118-129. https://doi.org/10.1163/ 18786561-00601008

Climate Vulnerable Forum (2015) High Level Climate Vulnerable Forum Meeting at COP21. http://www.thecvf.org/web/programevents/ 2015-forum/. Accessed 28 Sept 2017

Davis WJ (1996) The Alliance of Small Island States (AOSIS): the international conscience. Asia-Pac Mag 2:17-22

de Águeda Corneloup I, Mol APJ (2014) Small island developing states and international climate change negotiations: the power of moral "leadership". Int Environ Agreements: Polit Law Econ 14(3):281297. https://doi.org/10.1007/s10784-013-9227

Duvat VK, Magnan AK, Wise RM, Hay JE, Hinkel J, Stojanivic TA, Yamano H, Ballu V (2017) Trajectories of exposure and vulnerability of small islands to climate change. Wiley Interdiscip Rev Clim Chang E478. doi:https://doi.org/10.1002/wcc.478

Fry I (2016) The Paris Agreement: an insider's perspective-the role of Small Island Developing States. Environ Policy Law 46(2):105-108

Hoad D (2015) Reflections on small island states and the international climate change negotiations (COP21, Paris, 2015). Island Stud J 10(2):259-262 ISSN 1715-2593

Hoad D (2016) The 2015 Paris Climate Agreement: outcomes and their impacts on small island states. Island Stud J 11(1):315-320 ISSN $1715-2593$

IPCC (1990) The IPCC Impacts Assessment. Report prepared for IPCC by Working Group II. Edited by W.J. McG. Tegart, G.W. Sheldon and D.C. Griffiths 296 pages

IPCC (2016) Outline of the Special Report on the impacts of global warming of $1.5^{\circ} \mathrm{C}$ above pre-industrial levels and related global greenhouse gas emission pathways, in the context of strengthening the global response to the threat of climate change, sustainable development, and efforts to eradicate poverty. https:/www.ipcc.ch/ meetings/session44/12 adopted_outline_sr15.pdf

Jaschik K (2014) Small states and international politics: climate change, the Maldives and Tuvalu. Int Polit 51(2):272-293. https://doi.org/ 10.1057/ip.2014.5

Klein RJ, Möhner A (2011) The political dimension of vulnerability to the adverse effects of climate change. IDS Bull 42(3):15-22

Magnan AK, Schipper ELF, Burket M, Bharwani S, Burton I, Eriksen S, Gemenne F, Schaar J, Ziervogel G (2016) Addressing the risk of maladaptation to climate change. WIREs Clim Chang 7(5):646665. https://doi.org/10.1002/wcc.409
Mathiesen K, Harvey H (2015) Climate coalition breaks cover in Paris to push for binding and ambitious deal. The Guardian (8 December 2015)

Nurse L, McLean R, Agard J, Briguglio L, Duvat-Magnan V, Pelesikoti N, Tompkins E, Webb A (2014) Small Islands. In Field CB, Barros VR, Dokken DJ, Mach KJ, Mastrandrea MD, Bilir TE, Chatterjee M, Ebi KL, Estrada YO, Genova RC, Girma B, Kissel ES, Levy AN, MacCracken S, Mastrandrea PR, White LL (Eds.), Climate change 2014: impacts, adaptation, and vulnerability. Part B: regional aspects. Contribution of Working Group II to the Fifth Assessment Report of the Intergovernmental Panel on Climate Change, Cambridge University Press, Cambridge, United Kingdom and New York, NY, USA, 1613-1655

Ourbak T, Tubiana L (2017) Changing the game: the Paris Agreement and the role of scientific communities. Clim Pol 17(7):819-824. https://doi.org/10.1080/14693062.2017.1348331

PIF (2013) The Majuro Declaration. http://d3n8a8pro7vhmx.cloudfront. net/majurodeclaration/pages/25/attachments/original/1378363615/ 130905_RMI_PIF_Majuro_Declaration_Commitments.pdf? 1378363615. Accessed 28 Sept 2017

Rajamani L (2015) Addressing loss and damage from climate change impacts. Econ Polit Wkly 50(30):17-21

Rockström J, Gaffney O, Rogelj J, Meinshausen M, Nakicenovic N, Schellnhuber HJ (2017) A roadmap for rapid decarbonization. Science 355(6331):1269-1271. https://doi.org/10.1126/science. aah3443

Schleussner CF, Rogelj J, Schaeffer M, Lissner T, Licker R, Fischer EM, Knutti R, Levermann A, Frieler K, Hare W (2016) Science and policy characteristics of the Paris Agreement temperature goal. Nat Clim Chang 6:827-835. https://doi.org/10.1038/nclimate3096

UNFCCC (1992) https://unfccc.int/resource/docs/convkp/conveng.pdf

UNFCCC (2005) climate change, small island developing States. Issued by the CLIMATE CHANGE SECRETARIAT (UNFCCC), Bonn, Germany. http://unfccc.int/resource/docs/publications/cc_sids.pdf

UNFCCC (2015a) Paris Agreement. http://unfecc.int/files/essential background/convention/application/pdf/english paris agreement.pdf

UNFCCC (2015b) Decision 1/CP.21. https://unfecc.int/resource/docs/ 2015/cop21/eng/10a01.pdf

UNFCCC (2016a) Synthesis report on the aggregate effect of the intended nationally determined contributions: an update. FCCC/CP/2016/2. http://unfccc.int/resource/docs/2016/cop22/eng/ 02.pdf

UNFCCC (2016b) Non-state actor zone for climate action platform. $\mathrm{http} / /$ climateaction.unfccc.int/

UNFCCC (2017a) Paris Agreement-Status of Ratification. November $28^{\text {th }}$. http://unfccc.int/paris_agreement/items/9444.php. Accessed 28 Sept 2017

UNFCCC (2017b) Marshall Islands ratifies agreement on HFCs. First country to ratify "Kigali Amendment" November 28th. http:// newsroom.unfccc.int/climate-action/marshall-islands-first-countryto-ratify-kigali-amendment-on-hfcs/. Accessed 27 Sept 2017

Wong PP (2011) Small island developing states. WIREs Clim Chang 2:16. https://doi.org/10.1002/wcc. 84

Zartman IW, Rubin RJ (2002) Power and negotiation. The University of Michigan press. 305 pages 